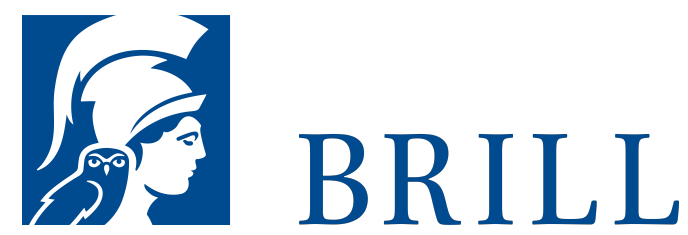

\title{
A Comparative Lexical Study of Qur'Ǟnic Arabic
}

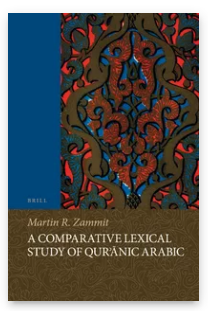

This work does not aim to be an etymological dictionary of Qur'Ä $\square$ nic Arabic, nor does it attempt to suggest some new genetic classification of the Semitic languages. Rather, it offers insights into the internal lexical relationships attested in a number of Semitic varieties.

The work is based on a quantitative analysis of a substantial corpus of the Arabic lexicon with a view to investigating lexical relationships within a number of Semitic languages. Qur'Ä $\square$ nic Arabic is the source of a lexical mass comparison exercise involving Akkadian, Ugaritic, Aramaic, Syriac, Hebrew, Phoenician, Epigraphic South Arabian and Geâ€ ez. Moreover, the lexical links identified in this study are in themselves linguistic indicators of the various degrees of cultural proximity characterising the various Semitic languages.

Readership

This work will provide valuable research material to all those interested in Semitic Studies in general or in the following Semitic languages in particular: Akkadian, Arabic, Aramaic, E.S.A., Geâ€ ez, Hebrew, Phoenician, Syriac, Ugaritic.

Pages: xiv, $65^{8}$

pp.

Language:

English

Subjects:

Literature,

Middle East and

Islamic Studies

Publisher: Brill

Series:

Handbook of

Oriental Studies.

Section 1 The

Near and Middle

East, Volume: 61

E-Book (PDF)

Released online:

11 Nov $202 \mathrm{O}$

ISBN: 978-90-

47-40051-6

List price

USD Â $\$ 215.00$

Hardback

Publication date:

o1 Nov 2001

ISBN: 978-90-

04-11801-O

List price

USD Â \$215.00

Paperback

Publication date:

$20 \mathrm{Feb} 2 \mathrm{O} 2 \mathrm{O}$ 
Martin R. Zammit, Ph.D. (1998), in Arabic and Semitic Studies, 04-43083-9 List price University of Malta, is a Lecturer of Arabic at the Department of Arabic and Near Eastern Studies, University of Malta.

For more information see brill.com

Order information: Order online at brill.com +44 330 333 0049 | customerservices@brill.com Submission information: brill.com/authors

Titles published by Brill | Fink, Brill | mentis or Brill | Schöningh: +49(o)71 5413279216 | brill@brocom.de 